\title{
Phylogeny of the genus Apodemus with a special emphasis on the subgenus Sylvaemus using the nuclear IRBP gene and two mitochondrial markers: cytochrome $b$ and 12S rRNA
}

\author{
J.R. Michaux, ${ }^{a, b, *}$ P. Chevret, ${ }^{b}$ M.-G. Filippucci, ${ }^{c}$ and M. Macholan ${ }^{d}$ \\ ${ }^{a}$ Unité de Recherches Zoogéographiques, Institut de Zoologie, Quai Van Beneden, 22, 4020 Liège, Belgium \\ ${ }^{\mathrm{b}}$ Laboratoire de Paléontologie - cc064, Institut des Sciences de l'Evolution de Montpellier (UMR 5554-CNRS), UM II, Place E. Bataillon, \\ 34095 Montpellier Cedex 05, France \\ c Dipartimento di Biologia, Università di Roma, "Tor Vergata" Via della Ricerca Scientifica, 00133 Rome, Italy \\ ${ }^{\mathrm{d}}$ Institute of Animal Physiology and Genetics, Academy of Sciences of the Czech Republic, Veveri 97, 60200 Brno, Czech Republic
}

Received 11 June 2001; received in revised form 8 November 2001

\begin{abstract}
Phylogenetic relationships among 17 extant species of Murinae, with special reference to the genus Apodemus, were investigated using sequence data from the nuclear protein-coding gene IRBP (15 species) and the two mitochondrial genes cytochrome $b$ and $12 \mathrm{~S}$ rRNA (17 species). The analysis of the three genes does not resolve the relationships between Mus, Apodemus, and Rattus but separates Micromys from these three genera. The analysis of the two mitochondrial regions supported an association between Apodemus and Tokudaia and indicated that these two genera are more closely related to Mus than to Rattus or Micromys. Within Apodemus, the mitochondrial data sets indicated that 8 of the 9 species analyzed can be sorted into two main groups: an Apodemus group, with A. agrarius, semotus, and peninsulae, and a Sylvaemus group, with uralensis, flavicollis, alpicola, sylvaticus, and hermonensis. The position of Apodemus mystacinus is ambiguous and might be either included in Sylvaemus or considered a distinct subgenus, Karstomys, more closely related to Sylvaemus than to Apodemus. Estimation of the divergence time for these taxa suggests a separation between 7 and $8 \mathrm{My}$ ago for the three groups (mystacinus and the two subgenera Apodemus and Sylvaemus). Within each subgenus, divergence times are between 5.4 and 6 My for Apodemus and between 2.2 and 3.5 My for Sylvaemus and mystacinus. (c) 2002 Elsevier Science (USA). All rights reserved.
\end{abstract}

\section{Introduction}

The speciose genus Apodemus is widespread throughout the Palearctic region. Morphologically, Apodemus seems distinct from both Mus and Rattus, perhaps indicative of an ancient isolation (early Vallesian) of its ancestor (Martin-Suarez and Mein, 1998). Nevertheless, DNA/DNA hybridization data (Catzeflis, 1987; Catzeflis and Denys, 1992; Catzeflis et al., 1993; P. Chevret, unpublished data) and sequence analyses (Martin et al., 2000; Suzuki et al., 2000) tend to associate Apodemus with Mus.

Since the review of Musser et al. (1996) all but one of the Apodemus species have been divided into two sub-

\footnotetext{
${ }^{*}$ Corresponding author. Fax: +33-4-67-14-36-10.

E-mail address: johan@isem.univ-montp2.fr (J.R. Michaux).
}

genera: Sylvaemus (including most of the western Palearctic species) and Apodemus (in which A. agrarius and the ancient eastern Palearctic Alsomys subgenus, excluding $A$. argenteus, are included). The remaining $A$. argenteus seems to be distinct from the others. This hypothesis has been confirmed by Serizawa et al. (2000) based on sequences from the mitochondrial cytochrome $b$ and the nuclear IRBP genes. Moreover, these authors proposed a fourth monotypic group, A. gurkha, the Himalayan field mouse.

At present, many questions concerning the phylogenetic relationships both of the genus Apodemus within the Murinae and between the different species within each of the Apodemus subgenera still remain unanswered.

According to several authors (Filippucci et al., 1989, 1996; Musser and Carleton, 1993; Musser et al., 1996; 
Orlov et al., 1996; Vorontsov et al., 1992), 13 different species are presently recognized within the subgenus Sylvaemus in the western Palearctic region: A. sylvaticus, Linnaeus (1758); A. flavicollis, Melchior (1834); A. alpicola, Heinrich (1952); A. uralensis, Pallas (1881); $A$. mystacinus, Danford and Alston (1877); A. hermonensis, Filippucci et al. (1989); A. fulvipectus, Ognev (1924); $A$. mosquensis, Orlov et al. (1996); A. ciscaucasicus, Orlov et al. (1996); A. ponticus, Sviridenko (1936); A. hyrcanicus, Vorontsov et al., 1992; A. arianus, Blanford (1881); and A. wardi, Wroughton (1908). Species within the subgenus Sylvaemus are phenotypically very similar, and traditional morphometrics are often at a loss to distinguish between them (Michaux et al., 2002; Zagorodnyuk, 1996). For this reason, several authors have employed protein electrophoresis (Britton-Davidian et al., 1991; Csaikl et al., 1980; Engel et al., 1973; Filippucci, 1992; Filippucci et al., 1996, 2002; Gemmeke, 1980; Hartl et al., 1992; Mezhzherin and Zykov, 1991) and traditional cytogenetics (Bulatova et al., 1991; Nadjafova et al., 1993; Zima, 1984) in an attempt to unravel relationships. Unfortunately, similar to morphometrics, cytogenetics were not successful in delimiting species, given the uniformity in karyotypic characteristics of this subgenus. More recently, new molecular methods such as restriction fragment length polymorphism (Chelomina, 1996; Michaux et al., 1996, 1998a, 1998b), random amplified polymorphic DNA (RAPD) (Bellinvia et al., 1999), and sequencing of mitochondrial and/or nuclear genes (Chelomina, 1998; Chelomina et al., 1998; Martin et al., 2000; Serizawa et al., 2000) were used with greater success. However, most of these studies included only a limited number of Sylvaemus species and although they gave very interesting results concerning the intraspecific and interspecific phylogenetic relationships within this subgenus, many inconsistencies among the different studies remain.

The aims of the present study were fourfold. First, we wanted to determine the sister group to the genus Apodemus, adding novel $12 \mathrm{~S}$ rRNA mitochondrial DNA sequences to the already existing data of Serizawa et al. (2000) and Suzuki et al. (2000). In addition, we followed a combined data approach (Kluge, 1989) using three genes (12S rRNA, cytochrome $b$, and IRBP, available for 15 taxa) in concert. Second, we wanted to clarify the phylogenetic relationships among six European and Near Eastern Sylvaemus species, A. sylvaticus, A. flavicollis, A. uralensis, A. alpicola, A. mystacinus, and $A$. hermonensis, using new sequences from two mitochondrial regions (cytochrome $b$ and 12S rRNA). Third, we wanted to propose more robust estimations of divergence dates between the different murine genera, the Apodemus subgenera, and the Sylvaemus species. Finally, we wanted to discuss the evolutionary history of this speciose genus.

\section{Material and methods}

\subsection{DNA sequencing of cytochrome $b, 12 S \mathrm{rRNA}$, and $I R B P$}

DNA was extracted from ethanol-preserved tissue for the species listed in Table 1 following Sambrook et al. (1989). These tissues were taken from the Apodemus tissue collection of J.R. Michaux and the mammal tissue collection housed at the Institut des Sciences de l'Evolution de Montpellier (Catzeflis, 1991). Whenever possible, we selected two individuals for each species (Table 1) to minimize the effect of long-branch attraction (Felsenstein, 1978).

A large portion of cytochrome $b$ (971 bp) was amplified using the Universal PCR primers L7 (5'-ACCAA TGACATGAAAAATCATCGTT-3') and H16 (5'-AC ATGAATYGGAGGY-CAACCWG-3') (Kocher et al., 1989). The complete $12 \mathrm{~S}$ rRNA was amplified using the PCR primers R1 and S2 (Sourrouille et al., 1995). Finally, the complete IRBP gene was amplified using the PCR primers I1, J1, I2, and J2 (Stanhope et al., 1992). Amplification reactions were carried out in $2 \times 50-\mu 1$ volumes including $25 \mu \mathrm{l}$ of each $2 \mu \mathrm{M}$ primer, $20 \mu \mathrm{l}$ of $1 \mathrm{mM}$ dNTP, $10 \mu \mathrm{l}$ of $10 \times$ reaction buffer, $10 \mu \mathrm{l}$ of purified water, and $0.2 \mu \mathrm{l}$ of $5 \mathrm{U} / \mu \mathrm{l}$ Promega taq DNA polymerase. Approximately $200 \mathrm{ng}$ of DNA extract was used per PCR amplification. Amplifications were performed in a Labover PTC 100 thermal cycler employing 33 cycles $\left(20 \mathrm{~s}\right.$ at $94^{\circ} \mathrm{C}, 30 \mathrm{~s}$ at $50^{\circ} \mathrm{C}$, and $1 \mathrm{~min} 30 \mathrm{~s}$ at $68^{\circ} \mathrm{C}$ ) with a final extension cycle of $10 \mathrm{~min}$ at $68^{\circ} \mathrm{C}$. PCR products were purified using the Ultra-free DA Amicon kit (Millipore) and directly sequenced. Both strands were sequenced using a Bigdye terminator (Perkin-Elmer) sequencing kit and ran on an ABI 310 (Applied Biosystems) automated sequencer.

\subsection{Sequence alignment and saturation analysis}

Published sequences for cytochrome $b, 12 \mathrm{~S}$ rRNA, and IRBP were extracted from GenBank (see Table 1) and aligned to our new sequences using the ED editor (MUST package; Philippe, 1993). The program AFAS (MUST package; Philippe, 1993) was used to combine the aligned matrices of IRBP, $12 \mathrm{~S}$ rRNA, and cytochrome $b$.

Following Hassanin et al. (1998) and Philippe and Douzery (1994), we examined the IRBP, cytochrome $b$, and $12 \mathrm{~S}$ rRNA data sets for saturation. Using the matrices of patristic and inferred substitutions calculated by PAUP 4b8 (Swofford, 2000), the pairwise numbers of observed differences was plotted against the corresponding values for inferred substitutions (Philippe and Douzery, 1994). The slope of the linear regression (S) was used to evaluate the level of saturation (Hassanin et al., 1998). When no saturation is observed in the data 
Table 1

References of rodent tissues used for the experiments

\begin{tabular}{|c|c|c|c|c|c|c|c|}
\hline Family & Subfamily & Species & Tissue sample & Geographic origin & $\begin{array}{l}\text { Accession numbers } \\
\text { (IRBP gene) }\end{array}$ & $\begin{array}{l}\text { Accession numbers } \\
\text { (cyt. } b \text { gene) }\end{array}$ & $\begin{array}{l}\text { Accession numbers } \\
\text { (12S rRNA) }\end{array}$ \\
\hline \multirow[t]{25}{*}{ Muridae } & Spalacinae & $\begin{array}{l}\text { Spalax ehrenbergi } \\
\text { Spalax zemni }\end{array}$ & $\begin{array}{l}\text { T-1016 } \\
\text { GenBank }\end{array}$ & Diyarbakir, Turquie & Stanhope et al. (1996) & AJ311138 & Chevret et al. (2001) \\
\hline & Cricetinae & Cricetulus griseus & GenBank & & Suzuki et al. (2000) & Suzuki et al. (2000) & \\
\hline & & Cricetulus migratorius & $\mathrm{T}-325$ & IZEA Lausanne élevage & & & Hänni et al. (1999) \\
\hline & Murinae & Diplothrix legata & HS-1163 & & Suzuki et al. (2001) & Suzuki et al. (2001) & AJ311143 \\
\hline & & Tokudaia osimensis & T-XXX & & Suzuki et al. (2002) & Suzuki et al. (2002) & AJ311133 \\
\hline & & Mus musculus & GenBank & & Stanhope et al. (1992) & Bibb et al. (1981) & Sourrouille et al. (1995) \\
\hline & & Mus caroli & DNA-1413 & $\begin{array}{l}\text { Laboratory strain } \\
\text { (F. Bonhomme) }\end{array}$ & Suzuki et al. (2000) & Suzuki et al. (2000) & AJ279437 \\
\hline & & Rattus norvegicus & GenBank & & Suzuki et al. (2000) & Gadaleta et al. (1989) & Kobayashi et al. (1981) \\
\hline & & Micromys minutus & $\mathrm{T}-1196$ & Giverny (Orne, France) & Suzuki et al. (2000) & Suzuki et al. (2000) & AJ311139 \\
\hline & & Apodemus semotus & $\mathrm{T}-248$ & Taiwan: Mt. Ari & Serizawa et al. (2000) & Serizawa et al. (2000) & AJ311136 \\
\hline & & Apodemus peninsulae & $\mathrm{T}-668$ & $\begin{array}{l}\text { Baikalsk; Lake teletskoje; } \\
\text { Kracnojozsk }\end{array}$ & Serizawa et al. (2000) & Serizawa et al. (2000) & AJ311142 \\
\hline & & Apodemus agrarius & JRM-265 & $\begin{array}{l}\text { Czech Republic, } \\
\text { Koprivnice }\end{array}$ & Serizawa et al. (2000) & AJ311144 & AJ311130 \\
\hline & & & $\mathrm{T}-780$ & Estonia, Tallin & & AJ311145 & AJ311140 \\
\hline & & Apodemus mystacinus & JRM-261 & Syria & AJ311158 & AJ311146 & AJ311141 \\
\hline & & & JRM-281 & Greece, Peloponnese & & AJ311147 & AJ311132 \\
\hline & & Apodemus sylvaticus & JRM-168 & Italy, Latium, Rome & Serizawa et al. (2000) & AJ311148 & AJ311126 \\
\hline & & & JRM-269 & $\begin{array}{l}\text { France, Pyrénées- } \\
\text { Orientales }\end{array}$ & & AJ311149 & AJ311131 \\
\hline & & Apodemus flavicollis & JRM-199 & Italy, Abruzzo, Penne & Serizawa et al. (2000) & AJ311150 & AJ311127 \\
\hline & & & $\mathrm{T}-666$ & France, Allier & & AJ311151 & AJ311164 \\
\hline & & Apodemus alpicola & JRM-202 & France, Savoie & Serizawa et al. (2000) & AJ311152 & AJ311137 \\
\hline & & & $\mathrm{T}-1595$ & Austria, Vorarlberg & & AJ311153 & AJ311135 \\
\hline & & Apodemus uralensis & JRM-257 & Czech Republic, Moravia & & AJ311154 & AJ311128 \\
\hline & & & JRM-258 & Turkey, Yalnizcam gecidi & & AJ311155 & AJ311125 \\
\hline & & Apodemus hermonensis & JRM-259 & Turkey, Hakkari & & AJ311156 & AJ311134 \\
\hline & & & JRM-260 & Turkey, Dogubayazit & & AJ311157 & AJ311129 \\
\hline
\end{tabular}

Note. The taxonomic arrangements follow Wilson and Reeder (1993). The GenBank accession numbers are given for the new sequences obtained in this study. 
set, the slope equals one, whereas the slope tends toward zero as the level of saturation increases.

\subsection{Phylogenetic reconstructions}

Phylogenetic analyses followed three approaches. First, we analyzed each gene separately. Second, we used the combined matrix for IRBP (782 bp), 12S rRNA (904 bp), and cytochrome $b$ (971 bp) sequences to determine the phylogenetic position of Apodemus within Murinae. Third, to determine the relationships within Apodemus and more precisely within the subgenus $\mathrm{Syl}$ vaemus, we used a combined matrix of $12 \mathrm{~S}$ rRNA (904 bp) and cytochrome $b$ (971 bp) sequences.

Before combining these different genes into single matrices, the level of incongruence between genes was tested using PAUP4b5 (option Hompart). This approach uses the incongruence length difference (ILD) test with the parsimony criterion; 1000 randomizations were performed on variable sites only (Farris, 1985).

The aligned sequences were treated by different approaches: the GTR and the Kimura two-parameter (K2P) estimator were used for the calculation of genetic distances. The GTR analyses were performed assuming a gamma distribution for substitution rates across sites, where the parameter alpha (Yang, 1996) and the proportion of invariant sites were estimated with the maximum-likelihood (ML) method assuming the GTR phylogeny using PAUP 4.0b8. Maximum-parsimony (MP: heuristic search; TBR branch swapping option) and maximum-likelihood (GTR model of sequence evolution) analyses were also conducted using PAUP 4.0b8 (Swofford, 1998).

The robustness of inferences was assessed by bootstrap resampling (1000 random repetitions for MP and distance analyses and 100 for ML). Bremer's support index (BSI) (Bremer, 1988) was also calculated on the most parsimonious tree with enforcement of topological constraints.

Likelihoods of alternative topologies were compared with MOLPHY 2.3b3 (Adachi and Hasegawa, 1996) and PUZZLE (Strimmer and von Haeseler, 1996). Following Kishino and Hasegawa (1989), an alternative hypothesis was rejected when $\delta \ln L>1.96 \mathrm{SE}$, where $\delta \ln L$ is the difference between the $\log$-likelihoods of the best and the evaluated trees, and SE is the standard error of this difference.

\subsection{Divergence time}

To determine divergence times within Apodemus and more particularly within Sylvaemus, we used cytochrome $b$ and 12S rRNA. These two genes were chosen since they comprised full data for the majority of the species. Two calibration points derived from paleontological data were used: first, the Mus/Rattus dichotomy at 12 millions years (My) ago (Jacobs and Downs, 1994; Jacobs et al., 1989, 1990; Jaeger et al., 1986), and second, the divergence time between A. mystacinus and all the "small" Sylvaemus species estimated at approximately 7 My (Aguilar and Michaux, 1996; Michaux et al., 1997).

To determine whether there are differences in rates of cytochrome $b$ and 12S rRNA changes between the different murine genera included here, the Apodemus subgenera, and the Sylvaemus species, relative-rate tests were conducted with each of them against the remaining lineages. The relative-rate tests were done with RRTree, version 1.0 (Robinson et al., 1998), which improves the test of $\mathrm{Wu}$ and $\mathrm{Li}$ (1985) by taking into account taxonomic sampling and phylogenetic relationships. Relative-rate tests were performed at the subfamilial (Mus, Rattus, and Apodemus genera), subgeneric (among Apodemus subgenera), and intrasubgeneric (Sylvaemus species) levels. The two mitochondrial DNA regions (12S rRNA and cytochrome $b$ ) were analyzed separately. The ML tree for each gene was chosen as the reference topology. Micromys was used as outgroup. For coding sequences (cytochrome $b$ ), relative-rate tests were performed on the proportions of synonymous $\left(\mathrm{K}_{s}\right)$ and nonsynonymous $\left(\mathrm{K}_{a}\right)$ substitutions. For noncoding regions (12S rRNA), relative-rate tests were performed on the proportion of all the substitutions types $(\mathrm{K})$.

To apply a molecular clock and to estimate times of divergence, we estimated the ML (search constrained to clock-like evolution) tree based on the cytochrome $b$ data set with Micromys as outgroup. The inferred maximum-likelihood distances were used to estimate separation times.

\section{Results}

\subsection{New sequences}

All sequences generated in the present study were deposited in GenBank under Accession Nos. AJ311127 to AJ311143 and AJ311164 (12S rRNA), AJ311144 AJ311157 (cytochrome b), and AJ311158 (IRBP) (Table 1).

The alignment of the IRBP sequences of 15 taxa comprises 782 nucleotides of which $234(30 \%)$ are variable and $120(15 \%)$ parsimony informative. The average ratio of transition/transversion (TS/TV) is 2.39, ranging from 1.2 to 5.1 . The alignment of the cytochrome $b$ gene consists of 971 nucleotides for 24 taxa, 298 (37\%) of which are variable and $215(26 \%)$ parsimony informative. The average ratio of TS/TV is 1.79 , ranging from 0.80 (A. flavicollis (JRM-199)/Micromys minutus) to 5.34 (A. flavicollis (JRM-199)/A. hermonenis (JRM-260)). The complete alignment of the $12 \mathrm{~S}$ rRNA mitochondrial gene comprises 987 sites for 24 individuals. When the 
indels are removed from the matrix, 904 sites are included in the analyses, 455 in loops and 499 in stems. Of these $258(29 \%)$ are variable and $139(15 \%)$ parsimony informative. The average ratio of TS/TV is 1.56 , ranging from 0.8 to 6.7. The concatenated data matrix for the 15 species of Muridae comprises 2657 nucleotide sites, 776 $(29 \%)$ variable and $451(26 \%)$ parsimony informative.

\subsection{Saturation Analysis}

Saturation analysis of the IRBP data set (15 taxa, 782 nucleotides) indicates that there is no saturation for transition and transversion at 1 st and 2 nd codon positions, with slopes (S) ranging from 0.91 to 0.97 , and only light saturation for the 3rd codon position (TS: $S=0.81$; $\mathrm{TV}: \mathrm{S}=0.76$ ). Therefore we included all events at the three codon positions for all phylogenetic analyses.

Saturation analyses of the 12S rRNA data sets were performed on four partitions: transitions and transversions were analyzed separately in loop and stem regions. There is no saturation for TV in stems $(S=0.99)$ and only moderate saturation for TS in stems $(S=0.80)$ and for both substitution types in loops (TS: $\mathrm{S}=0.76$; $\mathrm{TV}$ : $\mathrm{S}=0.73$ ).

Saturation analysis of the cytochrome $b$ data showed that TS and TV at positions 1 and 2 and TV at position 3 are moderately affected by homoplasy (TS $1: \mathrm{S}=0.59$; TV 1: $\mathrm{S}=0.69$; TS 2: $\mathrm{S}=0.54$; TV 2: $\mathrm{S}=0.98$; TV 3: $\mathrm{S}=0.52$ ). In contrast, transitions at $3 \mathrm{rd}$ position are highly saturated $(S=0.26)$. Therefore, all further analyses were conducted excluding TS at 3 rd codon position.

\subsection{Phylogenic relationships of Apodemus within the Murinae}

Notwithstanding minor discrepancies between the branching patterns obtained from the $12 \mathrm{~S}$ rRNA and those from the cytochrome $b$ data sets, the ILD test showed no significant incongruence between the two mitochondrial markers $(P=0.15)$. Despite significant incongruences (see below for some examples of incongruence between the different topologies) found when all three genes are combined $(P=0.001)$, we chose to concatenate these three genes for the 15 species common to these markers. This allowed us more sites for analysis and a combination of one nuclear and two mitochondrial markers.

The combined analysis was performed with two nonmurine species of Muridae (Cricetulus (Cricetinae) and Spalax (Spalacinae)) as outgroups. A consensus tree, constructed from the topologies retrieved by MP, ML, and neighbor-joining with bootstrap support (NJB), is presented in Fig. 1. For the NJ analysis, branching patterns and bootstrap values were similar using either MUST or PAUP. The monophyly of the
Murinae is strongly supported $(\mathrm{MP}=100 /+36$; $\mathrm{NJ}=100 ; \mathrm{ML}=76$ ). The most basal murine genus is Micromys $(\mathrm{MP}=60 /+7 ; \mathrm{NJ}=75)$. Three main groups can be distinguished for the remaining Murinae taxa: a Rattus-Diplosthrix group, Mus, and Apodemus-Tokudaia. The monophyly of both Rattus-Diplothrix $(\mathrm{MP}=100 /+50 ; \quad \mathrm{NJB}=100 ; \quad \mathrm{ML}=100) \quad$ and $M u s$ $(\mathrm{MP}=100 /+39 ; \mathrm{NJB}=100 ; \mathrm{ML}=100)$ is well supported. The support for Apodemus-Tokudaia is moderate with the three methods $(\mathrm{MP}=47 /+4 ; \mathrm{NJB}=73$; $\mathrm{ML}=55$ ). Based on the combined data set, it is impossible to determine sister group relationships among Rattus-Mus-Apodemus. One reason for this lack of resolution is that mitochondrial and nuclear data sets provide conflicting results. The mitochondrial data support Mus and Apodemus as sister taxa, whereas the IRBP data associate Mus and Rattus to the exclusion of Apodemus, hence an unresolved multitomy in the combined analysis. Interestingly, Apodemus and Rattus are never grouped together. At a lower taxonomic level, the genus Apodemus appears monophyletic ( $\mathrm{MP}=75 /+7$; $\mathrm{NJB}=88 ; \mathrm{ML}=68$ ) and is divided into three groups: $A$. mystacinus; a Sylvaemus group containing flavicollis, alpicola and sylvaticus; and an Apodemus group including agrarius, semotus, and peninsulae. Within the subgenus Apodemus, semotus, and peninsulae are more closely related to each other than to agrarius, whereas within Sylvaemus, alpicola, and flavicollis are more closely related than either of them are to sylvaticus. A. mystacinus is related to Sylvaemus although with a low support $(\mathrm{MP}=40 / 0 ; \mathrm{NJB}=61 ; \mathrm{ML}=41)$.

\subsection{Phylogenetic analysis within apodemus}

To determine relationships within the genus Apodemus and the subgenus Sylvaemus, we focused our analyses on the murine taxa, with a larger mitochondrial DNA sampling of Apodemus species. We included two individuals from each of the different species of $S y l$ vaemus, alpicola, uralensis, flavicollis, sylvaticus, and hermonensis, two mystacinus and agrarius specimens, and one sample each from semotus and peninsulae. Tokudaia, Micromys, Rattus, Diplothrix, and Mus were also included in the analysis. We used Micromys to root the topologies (see Fig. 1).

The results from the different analyses are presented in Fig. 2. Again, for the NJ analysis, branching patterns and bootstrap values were similar using either MUST or PAUP. Mus appeared more closely related to Apodemus ( $\mathrm{MP}=76 /+4 ; \quad \mathrm{NJB}=74 ; \quad \mathrm{ML}=88)$ than to Rattus. Although not statistically supported $(\mathrm{MP}=34 / 0$; $\mathrm{NJB}=48 ; \mathrm{ML}=76$ ), all three methods grouped Tokudaia as sister taxon to Apodemus, the latter representing a monophyletic group $(\mathrm{MP}=54 /+2 ; \mathrm{NJB}=68 ; \mathrm{ML}=73)$.

Within Apodemus, the monophyly of the different species, when represented by two individuals, are well 


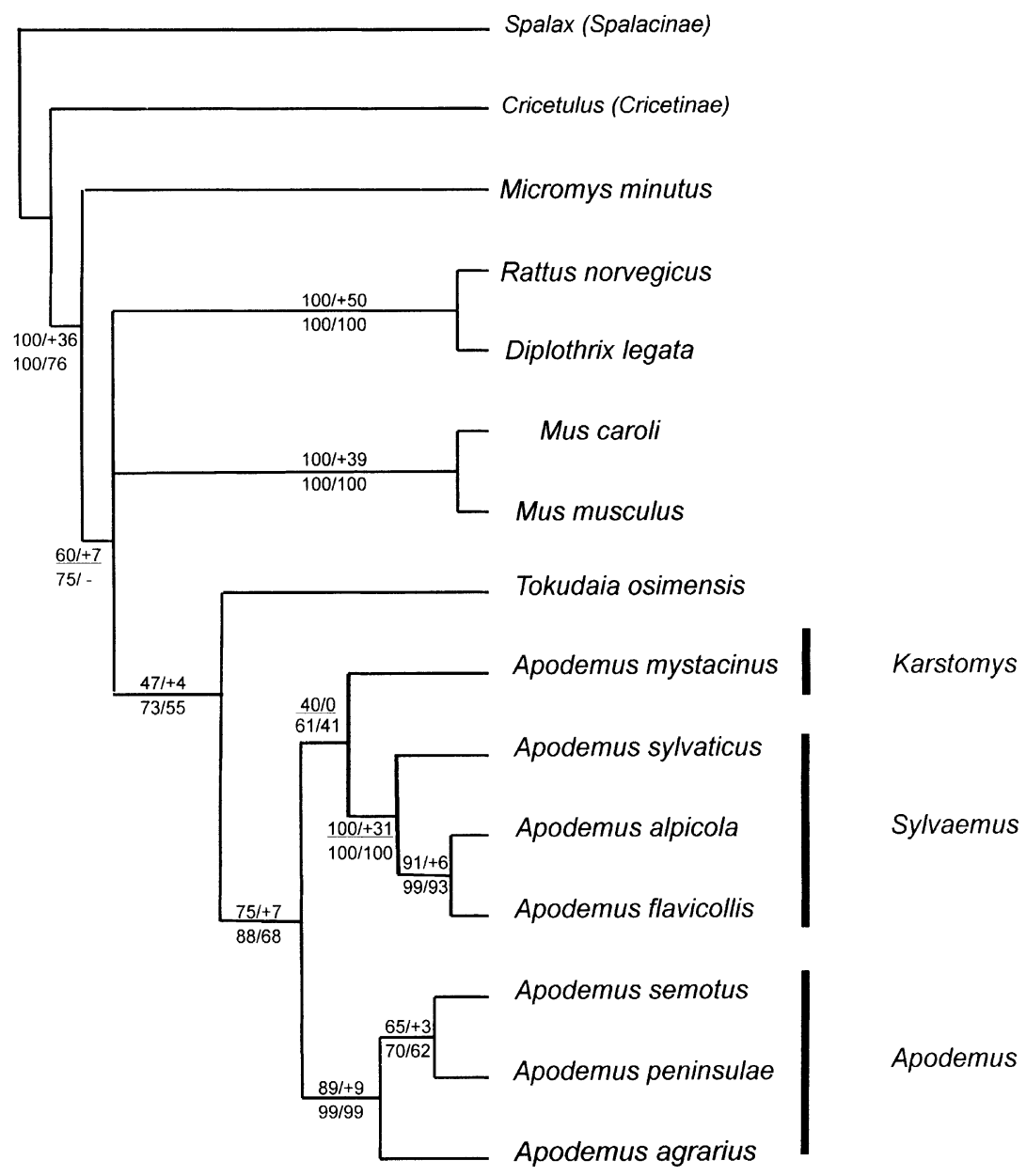

Fig. 1. Consensus tree obtained from the analysis of the concatenation of the three genes for 15 taxa and 2657 positions, with the exclusion of transitions at 3rd codon positions for the cytochrome $b$. Spalax and Cricetulus are used to root the tree. Apodemus subgenera names are indicated on the right side. For each node the different robustness indices are indicated as

Maximum--parsimony bootstrap support/BSI

NJBoot support/ML Bootstrap support

When conflicting relationships are obtained wuth the different analysis a trichotomy is indicated.

supported ( $=98-100 \%)$. The Apodemus subgenus comprises agrarius, semotus, and peninsulae $(\mathrm{MP}=60 /+3$; $\mathrm{NJB}=82 ; \mathrm{ML}=67)$ with semotus and peninsulae more closely related to each other $(\mathrm{MP}=63 /+3 ; \mathrm{NJB}=52$; $\mathrm{ML}=63$ ) than they are to agrarius. A. mystacinus is more closely related to Sylvaemus than to the Apodemus subgenus $(\mathrm{MP}=74 /+7 ; \mathrm{NJB}=75 ; \mathrm{ML}=71)$.

Within Sylvaemus, alpicola, and uralensis are sister species $(\mathrm{MP}=74 /+3 ; \mathrm{NJB}=67 ; \mathrm{ML}=72)$. These two species cluster with flavicollis $(\mathrm{MP}=91 /+5 ; \mathrm{NJB}=91$; $\mathrm{ML}=81)$. A. sylvaticus is associated either with the flavicollis group $(\mathrm{MP}=56 /+2 ; \mathrm{ML}=45)$ or with $A$. hermonensis $(\mathrm{NJB}=71)$.

A summary of the Kimura two-parameter sequence divergence values is presented in Table 2 for the three regions, both within and between the studied genera. Both nuclear (1RBP) and mitochondrial (12S rRNA) sequences indicate a close relationship between mystac- inus and Sylvaemus (3.6 and 4.8\%, respectively, versus 4.5 and $5.2 \%$ between mystacinus and Apodemus), whereas cytochrome $b$ shows the three groups to be equidistant $(8.8 \%)$. Genetic divergence values within the Apodemus subgenus appear higher (average of 3.8\%, 5\%, and $6.8 \%$ for IRBP, $12 \mathrm{~S}$ rRNA, and cytochrome $b$, respectively) than those within Sylvaemus (average of $1.3 \%, 2 \%$, and $4 \%$ ). Finally, the divergence between the two mystacinus specimens coming from different regions (Greece and Syria) is in the same order $(2.5 \%$ for $12 \mathrm{~S}$ rRNA and $4.4 \%$ for cytochrome $b$ ) as those observed within the Sylvaemus subgenus.

\subsection{Likelihoods of alternative topologies}

Given that the partition homogeneity test (Farris, 1985) indicated some conflict between the data sets, it was not surprising to find different topologies in the 


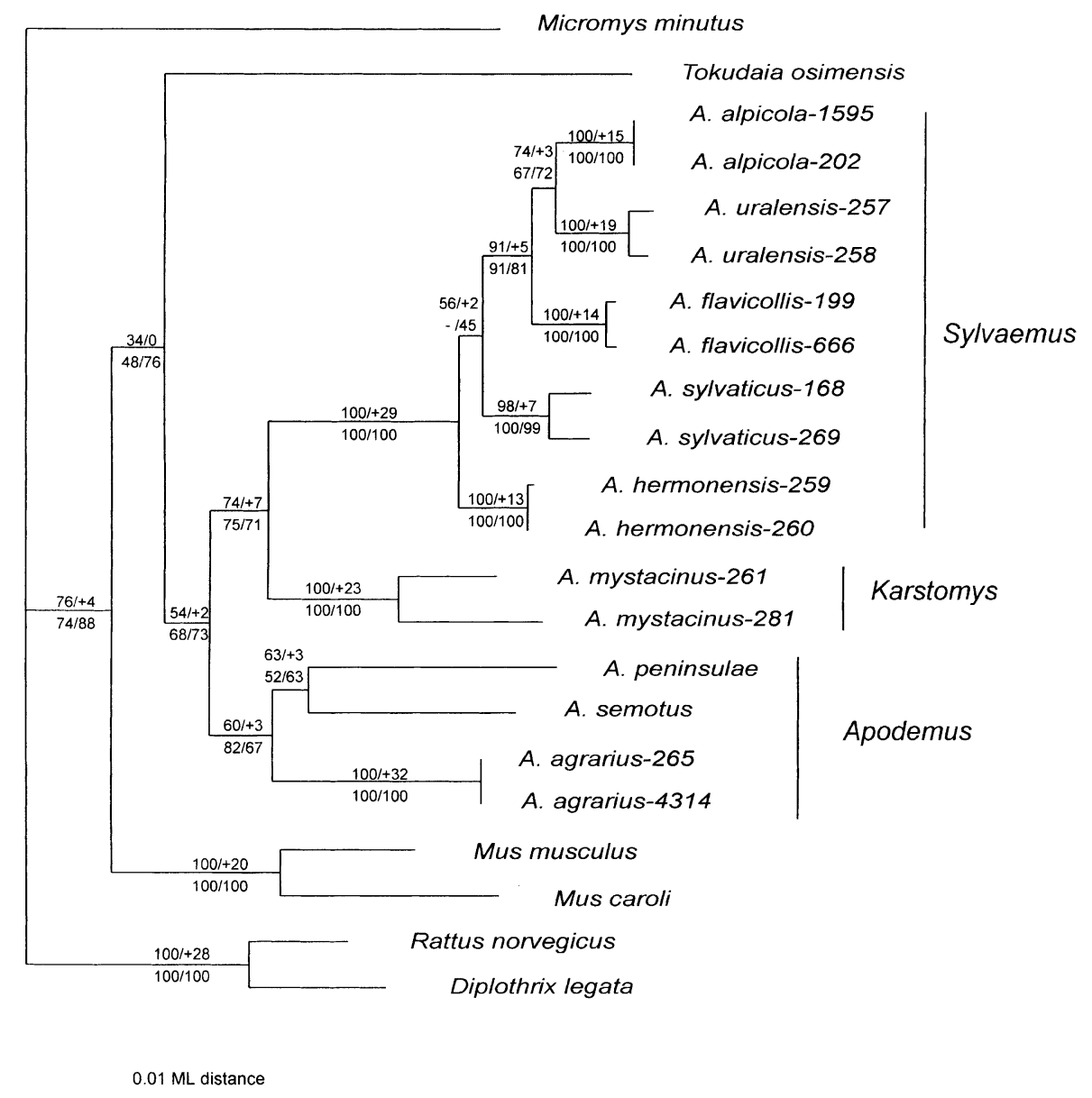

Fig. 2. Highest-likelihood tree derived from the analysis of the concatenation of the two mitochondrial genes for 22 taxa and 1875 positions, with the exclusion of transition at $3 \mathrm{rd}$ codon position for the cytochrome b. Micromys is used to root the tree. Each Apodemus sample is identified by its name and DNA number. Subgenera names are indicated on the right side. For each node the different robustness indices are indicated as

$\frac{\text { Maximum--parsimony bootstrap support/BSI }}{\text { NJBoot support/ML Bootstrap support }}$.

Table 2

Degree of within- and between-genus sequence divergence with Kimura two-parameter distance for the IRBP, 12S, and cytochrome $b$ genes

\begin{tabular}{llll}
\hline Taxa compared & IRBP d (all events) & $12 \mathrm{~S} \mathrm{~d}$ (all events) & Cytochrome $b$ d (12 TVTS + 3 TV) \\
\hline Among the Murinae genera & $7.2 \%(5.7-8.2)$ & $7.7 \%(7.1-8.3)$ & $10.6 \%(9.8-12.1)$ \\
Diplothrix/Rattus & $1.80 \%$ & $3.8 \%$ & $3.4 \%$ \\
Apodemus subgenus/Sylvaemus & $4.8 \%(3.9-5.8)$ & $6.2 \%(4.8-6.9)$ & $8.5 \%(7.3-10)$ \\
Apodemus subgenus/Karstomys & $4.5 \%(3.8-5.1)$ & $5.2 \%(4.8-5.5)$ & $8.8 \%(8.3-10)$ \\
Karstomys/Sylvaemus & $3.6 \%(3.5-3.7)$ & $4.8 \%(4-5.4)$ & $8.8 \%(7.9-9.9)$ \\
Within the Apodemus subgenus & $3.8 \%(3.7-3.8)$ & $5.0 \%(4.8-5.3)$ & $6.8 \%(6.8-6.9)$ \\
Within the Sylvaemus subgenus & $1.3 \%(1.1-1.4)$ & $2.0 \%(1.3-2.8)$ & $4.0 \%(3.2-4.5)$ \\
mystacinus Europe/Near East & - & $2.5 \%$ & $4.4 \%$ \\
\hline
\end{tabular}

IRBP and mitochondrial DNA gene trees. We wanted to determine whether either of these conflicting topologies were significantly better. To this end, we constructed the highest-likelihood tree for each of the IRBP and combined mtDNA data sets. The tree obtained from the IRBP data ( $\operatorname{Ln} L=-3067.88)$ included 15 murid species, whereas the one based on the cytochrome $b+12 \mathrm{~S}$ rRNA sequences $(\operatorname{Ln} L=-9381.73)$ included 24 murine sequences. They were identified with PUZZLE (Strimmer and von Haeseler, 1996) among 945 alternative trees constructed using MOLPHY 2.3b3 (Adachi and Hasegawa, 1996). 
The best tree obtained from the two mitochondrial genes was identical to the one presented in Fig. 2. The IRBP topology was similar with the exception that it relates Mus to Rattus rather than to the TokudaiaApodemus group.

These two trees with the highest likelihoods were used as reference topologies to apply the test of Kishino and Hasegawa (1989) $(\mathrm{KH})$ on each DNA data set for assessing the following phylogenetic relationships: (1) Mus, Apodemus, and Rattus; (2) Tokudaia and Apodemus; (3) Apodemus mystacinus and Sylvaemus; and (4) Sylvaemus species (mitochondrial gene matrices only). To do so, we tested different alternative hypotheses derived from traditional morphological, paleontological, and molecular studies (Table 3 ).

For the tests based on the IRBP tree, none of the alternative topologies exhibited a significantly worse log-likelihood score than the highest-likelihood IRBP tree (Table 3). In sharp contrast, for the combined cytochrome $b$ and $12 \mathrm{~S}$ rRNA, the alternative hypotheses 1 , $3,7,8,10,11$, and 12 exhibited significantly worse loglikelihood scores (Table 3). It appears that the most probable relationships are similar to those observed in Fig. 2 with the exception of the distinct placement of $A$. hermonensis with regard to the other Sylvaemus species.

\subsection{Divergence time}

The relative-rate test (Robinson et al., 1998) indicated no significant rate heterogeneity (both $\mathrm{K}_{s}$ and $\mathrm{K}_{a}$ ) for cytochrome $b$ in the different murine genera, Apodemus subgenera, and Sylvaemus species. On the contrary, K comparisons for the 12S rRNA showed marked differences in evolutionary rates with both Mus and $A$. mystacinus exhibiting an elevated rate compared to the other taxa. This excluded the use of the $12 \mathrm{~S}$ rRNA data for divergence estimates since both Mus and A. mystacinus are calibration points.

The ML distance between Mus and Rattus that diverged $12 \mathrm{My}$ ago is 0.101 . The one between $\mathrm{A}$. mys- tacinus and all remaining Sylvaemus that diverged $7 \mathrm{My}$ ago is 0.059 . These values give a rate of 0.0084 (Mus/ Rattus and mystacinus/other Sylvaemus) ML distance per million years. When this rate is applied to the different dichotomies within the Murinae, the following molecular datings are obtained: $9.7 \mathrm{My}$ for the separation between Mus and Tokudaia-Apodemus and 7.9 My for the separation between the Apodemus and the Sylvaemus subgenera (see Table 4).

\section{Discussion}

\subsection{Relationships of Apodemus to other Murinae}

According to our data, the closest murine relative of Apodemus is Tokudaia, an endemic genus from Ryukyu Island, Japan. Notwithstanding moderate support, this finding confirms the phylogenetic hypothesis of $\mathrm{Ka}$ wamura (1989) who proposed that Tokudaia is included in a group that contains Apodemus, Pliocene Rhagapodemus, and Quaternary Rhaghamys. In the same way, Misonne (1969) included Tokudaia in his LenothrixParapodemus division but closer to Lenothrix than to Apodemus, with a possible origin in the Philippine Islands.

From a molecular point of view, Suzuki et al. (2000) proposed two conflicting topologies (Tokudaia-Mus (cytochrome $b$ ) and Tokudaia-Micromys (IRBP). The former association was, however, not supported $(\mathrm{BP}=33 \%)$ and appears as an unresolved trichotomy between Mus, Apodemus, and Tokudaia. The same authors proposed two possible events for the colonization of the Islands by Tokudaia, either an ancient (12-14 My) or a recent (3-4 My) colonization event. We estimated an age of $9.6 \mathrm{My}$ (Table 4) for the divergence between Apodemus and Tokudaia, a date which is more consistent with the second hypothesis.

In our analysis, the Tokudaia-Apodemus group either falls in a trichotomy with Mus and Rattus (combined

Table 3

Alternative hypotheses derived from traditional morphological, paleontological, and molecular studies

\begin{tabular}{lll}
\hline Hypotheses & IRBP tree & Cytochrome $b-12 S$ RNA tree \\
\hline Mus, Rattus, and Apodemus as a trichotomy (our combined analysis) & No & Yes \\
Mus sister group to Rattus (our IRBP data) & No & Yes \\
Tokudaia basal to Apodemus (Suzuki et al., 2000) & No & Yes \\
Apodemus mystacinus basal to Sylvaemus (Storch, 1975) & No & Yes \\
Apodemus hermonensis sister group of A. flavicollis (Filippucci et al., 1996) & No & No \\
A. hermonensis basal to the other Sylvaemus & No & Yes \\
A. sylvaticus sister group to A. uralensis (Martin et al., 2000) & No & Yes \\
A. sylvaticus sister group to A. alpicola (Bellinvia et al., 1999) & No & Yes \\
A. uralensis basal to the other Sylvaemus (Martin et al., 2000) & \\
\hline
\end{tabular}

Note. They were tested using the test of Kishino and Hasegawa (1989). The highest-likelihood trees obtained from the two mitochondrial genes or the nuclear IRBP gene were used as the reference topologies. "Yes" indicates that the alternative topology exhibited a significantly worse loglikelihood score than the highest likelihood tree, whereas "No" signifies the contrary. 
Table 4

Estimates of the separation times of different events within muridae, on the basis of the molecular data

\begin{tabular}{|c|c|c|c|c|}
\hline Separation events & \multicolumn{2}{|l|}{ Separation } & \multicolumn{2}{|l|}{ Separation } \\
\hline A. mystacinus/other sylvaemus & 7 & - & 7 & 0.4 \\
\hline Diplothrix/Rattus & 2.6 & 0.5 & 2.7 & 0.5 \\
\hline Mus/Tokudaia, Apodemus & 9.7 & 0.3 & 9.7 & 0.3 \\
\hline agrarius/other Apodemus & 6 & 0.44 & 6 & 0.4 \\
\hline peninsulae/semotus & 5.4 & 0.49 & 5.4 & 0.4 \\
\hline mystacinus Europe/Near East & 3 & 0.4 & 3.1 & 0.4 \\
\hline Radiation of Sylvaemus & 3.5 & 0.27 & 3.5 & 0.2 \\
\hline flavicollis/other Sylvaemus & 2.6 & 0.2 & 2.6 & 0.2 \\
\hline uralensis/alpicola & 2.2 & 0.2 & 2.2 & 0.2 \\
\hline
\end{tabular}

Note. The numbers in boldface correspond to the two calibration points used for this analysis: 12 Myr for the separation between Mus and Rattus (Jaeger et al., 1986; Jacobs and Downs, 1994) and 7 Myr for the mystacinus/other Sylvaemus dichotomy (Aguilar and Michaux, 1996; Michaux et al., 1997). SE, standard error values provided by the maximum-likelihood analysis of Puzzle 4.0.

analysis of three genes) or is associated with Mus (mitochondrial data sets). The first possibility is certainly the result of a conflict between the nuclear (which rather associates Mus to Rattus) and the mitochondrial genes. However, the KH test shows that for IRBP, the association between Mus and Tokudaia-Apodemus is not significantly worse than that relating Mus to Rattus. Moreover, the second hypothesis is corroborated by dental morphology, which associates Apodemus closer to the Progonomys-Mus lineage than to the KarnimataRattus one (Jacobs and Downs, 1994; Jacobs et al., 1990), and previous molecular analyses (Catzeflis, 1987; Catzeflis et al., 1992, 1993; Suzuki et al., 2000; P. Chevret, unpublished).

\subsection{Basal position of Micromys}

It has been suggested that Micromys, the other Palearctic rodent included in our analysis, represents an early offshoot within the Murinae (Catzeflis et al., 1992; Furano et al., 1994). This association is based on the analysis of Line-1 (L1) repeated elements, more precisely a specific murine L1 subfamily named Lx (Furano et al., 1994), and scnDNA hybridization data (Catzeflis et al., 1992). Given that this genus has been known in Europe for only $5 \mathrm{My}$ (Aguilar et al., 1989) it may have originated earlier in Asia where the oldest Micromys was found in the Miocene of China (Storch, 1987). Our results based on the combined nuclear and mitochondrial data sets confirm with rather good support (distances and MP) its basal position within the Murinae.

The basal placement of Micromys contradicts with the results of Suzuki et al. (2000), who placed Micromys as sister group to either Rattus (cytochrome $b$ ) or Tokudaia (IRBP), and with the results of Martin et al. (2000), who clustered Micromys with Apodemus (ML) or
Rattus (MP). Neither of these contradicting placements received bootstrap support. A possible reason for these contradictions is the choice of Glirulus (Gliridae) as outgroup (Suzuki et al., 2000). This genus may be too distantly related to the Murinae, particularly when using cytochrome $b$. The tree that we constructed with Spalax (Spalacinae, Muridae) as outgroup indicates that $\mathrm{Mi}$ cromys either might be an early offshoot (distance, MP) or might be associated with Rattus (ML). In none of our analysis, whether we used the genes singly or in combination, did we find an association between Mus and Micromys or between Apodemus and Micromys. In Martin et al. (2000) the nodes that defined the basal divergences in the Murinae are very short and not robustly supported (bootstrap percentages below 50\% for most of the nodes that separate Mus, Rattus, Apodemus, and Micromys). Most of these nodes should therefore be represented as multitomies. Given the short internal branch lenghts, it is possible that the early murines underwent a rapid radiation between 14 and $12 \mathrm{My}$ ago, in which case the cytochrome $b$ gene might not be the most appropriate molecular marker to determine deeper relationships.

\subsection{Taxonomy and position of A. mystacinus}

A. mystacinus is distributed throughout the Balkan peninsula, Asia Minor, and the Middle-East. It is clearly distinguishable from the other Sylvaemus species based on morphology (Rietschel and Storch, 1973; Storch, 1975) and was therefore included in a separate subgenus: Karstomys Martino, 1939. However, the validity of this subgenus has been questioned with several authors recognizing mystacinus within Sylvaemus (Corbet, 1978; Musser et al., 1996; Niethammer and Krapp, 1978). Enzymatic polymorphism studies confirmed a differen- 
tiation of $A$. mystacinus with regard to the other Sylvaemus species (Britton-Davidian et al., 1991; Filippucci, 1992). However, the level of genetic distance between them falls within the range generally observed for species rather than subgenera. A recent RAPD study (Bellinvia et al., 1999) confirmed this result, although $A$. mystacinus seemed genetically more distant. On the contrary, cytochrome $b$ sequences (Martin et al., 2000) suggested that the genetic distance between four $\mathrm{Syl}$ vaemus species and A. mystacinus was too high to include mystacinus within Sylvaemus, therefore, maintaining Karstomys.

Our phylogenetic analyses clearly distinguish Karstomys from the Apodemus and Sylvaemus groups (Figs. 1 and 2). However, a close relationship between $A$. mystacinus and Sylvaemus is found and is confirmed by the Kishino and Hasegawa (1989) test. Taxonomically, our results are ambiguous: the cytochrome $b$ distance values separating $A$. mystacinus from the two other subgenera are of the same order as those observed between Apodemus and Sylvaemus (Table 2), suggesting a subgeneric status for A. mystacinus. On the contrary, the IRBP and 12S rRNA distance values observed between this species and the Sylvaemus group are similar to those observed within the Apodemus subgenus and would suggest a specific status for A. mystacinus within $S y l$ vaemus.

According to Felten et al. (1973), two subspecies should be recognized within the species mystacinus: epimelas occurring on the Balkan peninsula and mystacinus inhabiting Asia Minor and the Middle-East. Storch (1975), on the basis of variation in the first upper molar, proposed these as distinct species. Our results confirm an important level of genetic divergence between the animals from these two regions, similar to those observed between different Sylvaemus species (Table 2). The inclusion of a larger number of individuals covering the distribution area of this species is needed to resolve the taxonomic rank of the species.

\subsection{Phylogenetic relationships within the subgenus Sylvaemus}

The five recognized Sylvaemus species are closely related and form a well-supported monophyletic group. This result was already observed by Britton-Davidian et al. (1991), Filippucci (1992), Filippucci et al. (1996), Chelomina (1998), Martin et al. (2000), and Serizawa et al. (2000).

Within this subgenus, three groups are evident: a flavicollis group, A. hermonensis, and A. sylvaticus. Although we used a relatively large matrix (1875 bp), distance, parsimony, and maximum-likelihood analyses were not congruent with regard to the phylogenetic relationships between the three groups. This can be interpreted as the result of a bush-like radiation leading to the simultaneous emergence of many of Western Palearctic Sylvaemus species.

Our phylogenetic placement of $A$. hermonensis is at odds with the enzymatic analyses (Filippucci et al.1992, 1996) which suggest that $A$. hermonensis is closely related to A. flavicollis. The Kishino and Hasegawa (1989) test rejects this, but instead supports the distinctness of $A$. hermonensis with regard to the other Sylvaemus species. This result was already observed in Bellinvia et al. (1999) based on RAPD data.

The taxonomic relationships of $A$. hermonensis to the other oriental species are similarly problematic. In a recent morphological comparison between different populations of $A$. hermonensis from Turkey and Israel and specimens of $A$. fulvipectus from Ukraine and $A$. ponticus from Caucasus, Filippucci et al. (1996) concluded that $A$. hermonensis is probably a junior synonym of $A$. fulvipectus. The comparison of five A. hermonensis cytochrome $b$ sequences (data not shown) from different regions (Eastern Turkey, Israel, Iran) with partial sequences $(275 \mathrm{bp})$ of five fulvipectus specimens and three A. ponticus specimens (GenBank Accession Nos. AF249761-AF249768) from the Caucasus indicates that $A$. hermonensis is clearly distinct from A. fulvipectus (K2P values with all substitutions: $8.9 \%$ ) and from $A$. ponticus (K2P: 9.2\%), whereas the last two taxa seem more closely related to each other (K2P: $2.7 \%)$. Therefore, although our results have to be confirmed by the inclusion of additional sequences and genes, we propose that the specific status of $A$. hermonensis be retained for the time being.

Within the clade uniting A. flavicollis, A. uralensis, and $A$. alpicola (Fig. 2), the latter two species are sister taxa. This clade was described by Filippucci (1992) based on allozyme electrophoresis. Moreover, the alternative topologies tested with the Kishino and Hasegawa (1989) method were always significantly worse. However, other molecular studies (Britton-Davidian et al., 1991; Mezhzherin and Zykov, 1991; Chelomina, 1998; Bellinvia et al., 1999; Martin et al., 2000; Serizawa et al., 2000) provided conflicting results, supporting an association between $A$. sylvaticus and A. alpicola (Martin et al., 2000) or with A. uralensis (Bellinvia et al., 1999) opposed to A. flavicollis. However, since these studies had a much smaller species representation (between three and five) of European Sylvaemus species and since the sequence studies (Bellinvia et al., 1999; Chelomina, 1998; Martin et al., 2000; Serizawa et al., 2000) were based on one specimen per species, it will be difficult to compare our results with theirs. Moreover, after comparisons with several other sequences performed in our laboratory, it appears that the A. sylvaticus cytochrome $b$ sequence used in Martin et al. (2000) might be a nuclear mitochondrial pseudogene. This interpretation should now be tested with additional nuclear genes, encompassing at least a similar species 
diversity to ensure adequate representation of this speciose genus.

\subsection{Divergence time within Apodemus}

The molecular clock, based on two calibration points derived from paleontological data, gives us the opportunity to estimate the dates of divergence between and within studied genera (Table 4). Thus, it would appear that the three Apodemus groups considered in our study (Apodemus, mystacinus, and Sylvaemus) diverged roughly 7-8 My ago. According to isotopic studies (Cerling et al., 1997), this period was characterized by important climatic variations leading to drastic changes of vegetation all over the world. Indeed, in many regions and notably in the Holarctic area, the forest was greatly replaced by open herbaceous habitats. These changes in vegetation would have led to drastic faunal replacements, many woodland-adapted animals being replaced by more open-adapted species. If we postulate that the ancestors of Apodemus had the same ecological preference as all the recent Apodemus species, they would have occurred in broadleaf forests of the temperate zone. We could assume that some populations would have been isolated in refuges (forested regions) during this period, leading to isolation by distance and, in some instances, allopatric speciation of the different Apodemus subgenera. According to Cerling et al. (1997), the European regions were relatively protected from the climatic changes and were covered by forests. Therefore, Europe might have played an important role in the speciation of Apodemus. This hypothesis is corroborated by paleontological data which suggested the appearance of the true Apodemus species in Europe during the Turolian period (Michaux and Pasquier, 1974; Michaux et al., 1997; Martin-Suarez and Mein, 1998).

Within each subgenus, the estimated divergence times between the different species are 5.4-6 My for the Apodemus group and 2.2-3.5 My for the Sylvaemus and mystacinus groups. Thus it appears that the European species diverged more recently than the Asiatic species Serizawa et al. (2000) proposed that these divergences could be associated with floral and geological changes during the late Cenozoic. According to isotopic (Cerling et al., 1997) and palaeoclimatic (Fauquette et al., 1998, 1999; Fluteau et al., 1999) studies, the end of the Miocene and the Pliocene continued to be characterized by numerous climatic changes: from 7 to $4.5 \mathrm{My}$ ago, the climate, fauna, and vegetation of North America greatly varied. In the Palearctic region, from 5.3 to 3.1 My ago, the climate fluctuated between subtropical with warm and humid weather to cool and dry periods. From 3.1 My ago, rapid alterations of the climate which marked the first glacial periods of the Quaternary were observed (Fauquette et al., 1998). The vegetation tracked these climatic changes, being more forested during the warm and humid periods and more open landscape with steppe and forest-steppe during the cool and dry periods (Borisova, 1993; Fauquette et al., 1999, 1998).

A process similar to that described for the Miocene probably occurred during the Pliocene and led to different speciations within the Apodemus subgenera. The older divergence dates within the Apodemus subgenus could be explained by the fact that the climatic and vegetation variations appeared more dramatic in the eastern (Russia, Asia) than in the western regions (Borisova, 1993).

Apodemus primaevus, the ancestor of A. mystacinus, has been present in early Europe since the end of the Miocene (Michaux and Pasquier, 1974; Michaux et al., 1997). However, the true A. mystacinus only appeared during the Middle Pliocene (Martin-Suarez and Mein, 1998). During this period, the species was widespread throughout Europe, although with lower densities due to competition with many other rodents present at that time (Gliridae, Eomyidae, Sciuridae) (Michaux and Pasquier, 1974). We therefore hypothesize that one of the late Pliocene or early Pleistocene cooling periods associated with low population densities led to the disappearance of many animals and the isolation of the two main groups: one in the Balkanic region (where it is still confined at present) and the other in the Near East (Turkey, Israel). These led to the species A mystacinus and $A$. epimelas.

The ancestor ( $A$. dominans) of $A$. flavicollis and $A$. sylvaticus appeared more recently in Europe (toward the end of the Pliocene), probably coming from the eastern regions (Martin-Suarez and Mein, 1998; Michaux et al., 1997). It rapidly diverged and gave rise to the present species, probably as a result of an allopatric speciation. Indeed, at the beginning of the Pleistocene, $A$. sylvaticus was present only in Spain and southern France, whereas the distribution area of $A$. flavicollis was central Europe (Michaux and Pasquier, 1974).

The common ancestor of A. uralensis and A. alpicola could have been isolated in two populations during the first Pleistocene glacial events, respectively, in the eastern regions $(A$. uralensis is very rare in Western Europe during the Pleistocene, suggesting a late eastern colonization (Michaux and Pasquier, 1974)) and in the Alps, giving rise to these species.

\section{Conclusion}

Analyses of the nuclear protein-coding IRBP gene (15 species) and the two mitochondrial regions cytochrome $b$ and 12S rRNA (17 species) support an association between Apodemus and Tokudaia and indicate that these two genera are more closely related to $M u s$ than to Rattus or Micromys. Within Apodemus, the mitochon- 
drial data set indicates that 8 of the 9 species can be included in two main groups: an Apodemus group, with A. agrarius, semotus, and peninsulae, and a Sylvaemus group, with $A$. uralensis, A. flavicollis, A. alpicola, A. sylvaticus, and $A$. hermonensis. The 9th species, $A$. mystacinus, might be either included in Sylvaemus or considered a distinct subgenus, Karstomys, more closely related to Sylvaemus than to Apodemus. Within mystacinus, we showed an important level of genetic divergence between the animals from Europe and those from the Near East. This result could confirm specific status for each of these populations. Within Sylvaemus, we determined three groups: a flavicollis group, A. hermonensis, and A. sylvaticus. Unfortunately, our phylogenetic analyses do not resolve the relationships between these three groups. This could be interpreted as the result of a rapid bush-like radiation leading to the near simultaneous emergence of many of the Western Palearctic Sylvaemus species. Estimation of the divergence time of these taxa provide an age of 7-8 My for the divergence of the three Apodemus groups (mystacinus and the two subgenera, Apodemus, and Sylvaemus). Within each subgenus, divergence times are $5.4-6 \mathrm{My}$ for Apodemus and 2.2-3.5 My for Sylvaemus and mystacinus. These events could be linked to important climatic and vegetation variations during the end of the Miocene and Pliocene.

\section{Acknowledgments}

We thank Bettine Jansen van Vuuren and François Catzeflis for their comments on the manuscript. We thank François Catzeflis also for providing tissue samples from the collection of ethanol-preserved tissues of the Institut des Sciences de l'Evolution (Montpellier) and all people who provided tissue samples of rodent taxa: E. Nevo, M. Tranier, G. Armani, M. Harada, F. Catzeflis, O. Nikonova, E. Lyapunova, P. Vogel, and K. Tsuchiya. We also thank Olivier Verneau and Claire Tirard for laboratory help. Finally, a special thanks goes to Professor H. Suzuki who provided DNA samples of Diplothrix. This work was supported by a Belgian FNRS fellowship to J.R. Michaux (mandat "Chargé de Recherches") and the financial support of the Réseau National de Biosystématique (ACC-SV7). This is contribution ISEM-2001-110 of Institut des Sciences de l'Evolution de Montpellier (UMR 5554 CNRS).

\section{References}

Adachi, J., Hasegawa, M., 1996. MOLPHY: Programs for Molecular Phylogenetics, ver. 2.3 edit. Institute of Statistical Mathematics, Tokyo.

Aguilar, J.-P., Clauzon, G., Michaux, J., 1989. La limite Mio-Pliocène dans le sud de la France d'après les faunes de Rongeurs; état de la question et remarques sur les datations à l'aide des rongeurs. Boll. Soc. Paleontol. Italiana 28, 137-145.

Aguilar, J.-P., Michaux, J., 1996. The beginning of the age of Murinae (Mammalia: Rodentia) in southern France. Acta Zool. Cracoviensa 39, 35-45.

Bellinvia, E., Munclinger, P., Flegr, J., 1999. Application of the RAPD technique for a study of the phylogenetic relationships among eight species of the genus Apodemus. Folia Zool. 48, 241-248.

Bibb, M.J., Van Etten, R.A., Wright, C.T., Walberget, M.W., Clayton, D.A., 1981. Sequence and gene organization of mouse mitochondrial DNA. Cell 26, 167-180.

Borisova, O.K., 1993. Landscape and climate of the South-Central and Southeastern Russian plain during the Pliocene. Abstracts from a USGS workshop, Herndon, VA, p. 61.

Bremer, K., 1988. The limits of amino acid sequence data in angiosperm phylogenetic reconstruction. Evolution 42, 795-803.

Britton-Davidian, J., Vahdati, M., Benmehdi, F., Gros, P., Nancé, V., Croset, H., Guerassimov, S., Triantaphyllidis, C., 1991. Genetic differentiation in four species of Apodemus from Southern Europe: A. sylvaticus, A. flavicollis, A. agrarius, and A. mystacinus (Muridae, Rodentia). Z. Säugertierk. 56, 25-33.

Bulatova, N.S., Nadjafova, R.S., Kozlovsky, A.I., 1991. Cytotaxonomic analysis of species of the genera Mus, Apodemus, and Rattus in Azerbaijan. Z. Zool. Syst. Evol. 29, 139-153.

Catzeflis, F., 1987. Le rythme d' évolution de 1'ADN nucléaire dépend-il du temps de génération chez les mammifères. In: Actes Coll Nat CNRS. Biologic des Populations. University of C. Bernard, Lyon, France, pp. 63-68.

Catzeflis, F., 1991. Animal tissue collections for molecular genetics and systematics. Trends Ecol. Evol. 6, 168.

Catzeflis, F.M., Denys, C., 1992. The African Nannomys (Muridae) An early offshoot from the Mus lineage-evidence from scnDNA hybridization and compared morphology. Isr. J. Zool. 38, 219-231.

Catzeflis, F.M., Aguilar, J.-P., Jaeger, J.-J., 1992. Muroid rodents: phylogeny and evolution. Trends Ecol. Evol. 7, 122-126.

Catzeflis, F.M., Sheldon, F.H., Ahlquist, J.E., Sibley, C.G., 1987. DNA-DNA hybridization evidence of the rapid rate of muroid rodent DNA evolution. Mol. Biol. Evol. 4, 242-253.

Catzeflis, F.M., Dickerman, A.W., Michaux, J., Kirsch, J.A.W., 1993. DNA hybridization and rodent phylogeny. In: Szalay, F.S., Novacek, M.J., McKenna, M.C. (Eds.), Mammal Phylogeny. Springer, New York, pp. 159-172.

Cerling, T.E., Harris, J.M., MacFadden, B.J., Leakeys, M.G., Quade, J., Eisenmann, V., Ehleringer, J.R., 1997. Global vegetation change through the Miocene/Pliocene boundary. Nature 389, 153-157.

Chelomina, G.N., 1996. DNA restriction fragment length polymorphism in European and Asiatic wood mice species of the genus Apodemus. Genetika 32, 1381-1386.

Chelomina, G.N., 1998. Molecular phylogeny of forest and field mice of the genus Apodemus (Muridae, Rodentia) based on the data on restriction analysis of total nuclear DNA. Genetika 34, 1286-1292.

Chelomina, G.N., Suzuki, H., Tsuchiya, K., Moriwaki, K., Lyapunova, E.A., Vorontsov, N.N., 1998. Sequencing of the mtDNA cytochrome $b$ gene and reconstruction of the maternal relationships of wood and field mice of the genus Apodemus (Muridae, Rodentia). Genetika 34, 650-661.

Chevret, P., Catzeflis, F., Michaux, J., 1991. "Acomyinae:" new molecular evidences for a muroid taxon (Rodentia: Muridae). In: IRD (Eds.). Proceedings of the 8th ASM Symposium. Collection Colloques et séminaires. Special Volume. Paris (in press).

Corbet, G.B., 1978. The Mammals of the Palearctic Region: A Taxonomic Review. Br. Mus. (Nat. Hist.), London.

Csaikl, F., Engel, W., Schmidtke, J., 1980. On the biochemical systematics of three Apodemus species. Comp. Biochem. Physiol. 65, 411-414.

Engel, W., Vogel, W., Voiculescu, I., Ropers, R.R., Zenzes, M.T., Bender, M.K., 1973. Cytogenetic and biochemical differences 
between Apodemus sylvaticus and Apodemus flavicollis, possibly responsible for the failure to inbreed. Comp. Biochem. Physiol. 44b, 1165-1173.

Farris, J.S., 1985. Distance data revisited. Cladistics 1, 67-85.

Fauquette, S., Guiot, J., Suc, J.P., 1998. A method for climatic reconstruction of the Mediterranean Pliocene using pollen data. Palaeogeogr. Palaeoclimatol. Palaeoecol. 44, 183-201.

Fauquette, S., Clauzon, G., Suc, J.P., Zheng, Z., 1999. A new approach for palaeoaltitude estimates based on pollen records: example of the Mercantour massif (southeastern France) at the earliest Pliocene. Earth Planet. Sci. Lett. 70, 35-47.

Felsenstein, J., 1978. Cases in which parsimony and compatibility methods will be positively misleading. Syst. Zool. 27, 401-410.

Felten, H., Spitzenberger, F., Storch, G., 1973. Zur Kleinsäugerfauna West-Anatoliens. Teil II. Senckenberg. Biol. 54, 227-290.

Filippucci, M.G., 1992. Allozyme variation and divergence among European, Middle eastern, and North African species of the genus Apodemus (Rodentia, Muridae). Isr. J. Zool. 38, 193-218.

Filippucci, M.G., Simson, S., Nevo, E., 1989. Evolutionary biology of the genus Apodemus Kaup, 1829 in Israel. Allozymic and biometric analyses with description of a new species: Apodemus hermonensis (Rodentia, Muridae). Boll. Zool. 56, 361-376.

Filippucci, M.G., Macholan, M., Storch, G., 1996. Taxonomy of the genus Sylvaemus in western Anatolia-Morphological and electrophoretic evidence (Mammalia: Rodentia: Muridae). Senckenberg. Biol. 75, 1-14.

Filippucci, M.G., Macholan, M., Michaux, J., 2002. Genetic variation and evolution in the genus Apodemus (Muridae, Rodentia). Biol. J. Linn. Soc. (in press).

Fluteau, F., Ramstein, G., Besse, J., 1999. Simulating the evolution of the Asian and African Monsoons during the past $30 \mathrm{Myr}$ using an atmospheric general circulation model. J. Geophys. Res. 104, $11995-12018$.

Furano, A.V., Hayward, B.E., Chevret, P., Catzeflis, F., Usdin, K., 1994. Amplification of the ancient murine Lx family of long interspersed repeated DNA occurred during the murine radiation. J. Mol. Evol. 38, 18-27.

Gadaleta, G., Pepe, G., De Candia, G., Quagliariello, C., Sbisa, E., Saccone, C., 1989. The complete nucleotide sequence of the Rattus norvegicus mitochondrial genome: Cryptic signals revealed by comparative analysis between vertebrates. J. Mol. Evol. 28, 497516.

Gemmeke, H., 1980. Proteinvariation und Taxonomie in der Gattung Apodemus (Mammalia, Rodentia). Z. Säugetierk. 45, 348-365.

Hänni, C., Laudet, V., Barriel, V., Catzeflis, F.M., 1999. Evolutionary relationships of Acomys and other murids (Rodentia, Mammalia) based on complete $12 \mathrm{~S}$ rRNA mitochondrial gene sequences. Israel J. Zool. 41, 131-146.

Hartl, G.B., Suchentrunk, F., Willing, R., Markowski, J., Ansorge, H., 1992. Inconsistency of biochemical evolutionary rates affecting allozyme divergence within the genus Apodemus (Muridae, Mammalia). Biochem. Syst. Ecol. 20, 363-372.

Hassanin, A., Lecointre, G., Tillier, S., 1998. The "evolutionary signal" of homoplasy in protein-coding gene sequences and its consequences for a priori weighting in phylogeny. Compt. Rend. Acad. Sci. Paris 321, 611-620.

Jacobs, L.L., Downs, W.R., 1994. The evolution of murine rodents in Asia. In: Tomida, Y., Li, C., Setoguchi, T. (Eds.), Tokyo, pp. 149156.

Jacobs, L.L., Winkler, D.A., Murry, P.A., 1989. Modern mammal origins: evolutionary grades in the Early Cretaceous of North America. Proc. Natl. Acad. Sci. USA 86, 4992-4995.

Jacobs, L.L., Flynn, L.J., Downs, W.R., Barry, J.C., 1990. Quo vadis, Antemus? The Siwalik muroid record. In: Linday, E.H., Fahlbusch, V., Mein, P. (Eds.), European Neogene Mammal Chronology. Plenum Press, New York, pp. 573-586.
Jaeger, J.-J., Tong, H., Buffetaut, E., 1986. The age of Mus-Rattus divergence: paleontological data compared with the molecular clock. Compt. Rend. Acad. Sci. Paris Ser. 2 302, 917-922.

Kawamura, Y., 1989. Quaternary rodent faunas in the Japanese islands (Part 2). Mem. Fac. Sci. Kyoto Univ. Ser. Geol. Mineral. $54,1-235$.

Kishino, H., Hasegawa, M., 1989. Examination of the maximum likelihood estimate of the evolutionary tree topologies from DNA sequence data, and the branching order in Hominoidea. J. Mol. Evol. 29, 170-179.

Kluge, A.G., 1989. A concern for evidence and a phylogenetic hypothesis of relationships among Epicrates (Boidae, Serpentes). Syst. Zool. 38, 7-25.

Kobayashi, M., Seki, T., Yaginumaet, K., Koike, K., 1981. Nucleotide sequences of small ribosomal RNA and adjacent transfer RNA genes in rat mitochondrial DNA. Gene 16, 297-307.

Kocher, T.D., Thomas, W.K., Meyer, A., Edwards, S.V., Pääbo, S., Villablanca, F.X., Wilson, A.C., 1989. Dynamics of mitochondrial DNA evolution in animals: amplification and sequencing with conserved primers. Proc. Natl. Acad. Sci. USA 86, 6196-6200.

Martin, Y., Gerlach, G., Schlotterer, C., Meyer, A., 2000. Molecular phylogeny of European muroid rodents based on complete cytochrome $b$ sequences. Mol. Phylogenet. Evol. 6, 37-47.

Martin-Suarez, E., Mein, P., 1998. Revision of the genera Parapodemus, Apodemus, Rhagamys and Rhagapodemus (Rodentia, Mammalia). Geobios 31, 87-97.

Mezhzherin, S.V., Zykov, A.E., 1991. Genetic divergence and allozyme variability in mice genus Apodemus s. lato (Muridae, Rodentia). Cytol. Genet. 25, 51-58.

Michaux, J., Pasquier, L., 1974. Dynamique des populations de mulots (Rodentia, Apodemus) en Europe durant le Quaternaire. Premières données. B.S.G.F. 7 (XVI), 431-439.

Michaux, J., Aguilar, J.-P., Montuire, S., Wolff, A., Legendre, S., 1997. Les Murinae (Rodentia, Mammalia) néogènes du Sud de la France: Évolution et paléo environments. Geobios 20, 379-385.

Michaux, J.R., Filippucci, M.G., Libois, R.M., Fons, R., Matagne, R.F., 1996. Biogeography and taxonomy of Apodemus sylvaticus (the woodmouse) in the tyrrhenian region: Enzymatic variations and mitochondrial DNA restriction pattern analysis. Heredity 76, 267-277.

Michaux, J.R., Sara, M., Libois, R.M., Matagne, R., 1998a. Is the woodmouse (Apodemus sylvaticus) of Sicily really a "separate" species? Belgian J. Zool. 128, 211-214.

Michaux, J.R., Libois, R., Ramalhinho, M.G., Maurois, C., 1998b. On the mtDNA restriction patterns variation of the iberian wood mouse (Apodemus sylvaticus): comparison with other west Mediterranean populations. Hereditas 129, 187-194.

Michaux, J.R., Kinet, S., Filippucci, M.-G., Libois, R., Besnard, A., Catzeflis, C., 2002. Molecular characterization of three sympatric species of wood mice (Apodemus sylvaticus, A. flavicollis, and A. alpicola) in Europe (Muridae: Rodentia). Mol. Ecol. 1, 260-263.

Misonne, X., 1969. African and Indo-Australian Muridae: evolutionary trends. Ann. Mus. R. Afr. Centr. Tervuuren 172, 1-219.

Musser, G.G., Carleton, M.D., 1993. Family Muridae. In: Wilson, D.E., Reeder, D.M. (Eds.), Mammal Species of the World: A Taxonomic and Geographic Reference. Random House (Smithsonian Institute Press), Washington and London, pp. 501-755.

Musser, G.G., Brothers, E.M., Carleton, M.D., Hutterer, R., 1996. Taxonomy and distributional records of Oriental and European Apodemus, with a review of the Apodemus-Sylvaemus problem. Bon. Zool. Beitr. 46, 143-190.

Nadjafova, R.S., Bulatova, N., Chasovlikarova, Z., Gerassimov, S., 1993. Karyological differences between two Apodemus species in Bulgaria. Z. Säugertierk. 58, 232-239.

Niethammer, J., Krapp, F., 1978. Handbuch der Saugetiere Europas. Akad. Verlagsgesellschaft, Wiesbaden. 
Orlov, V.N., Kozlovsky, A.I., Nadjafova, R.S., Bulatova, N.S., 1996. Karyological diagnoses, distribution and evolutionary classification of wood mice of the subgenus Sylvaemus (Apodemus, Muridae, and Rodentia) in Europe. Zool. Z. 75, 88-102.

Philippe, H., 1993. MUST, a computer package for management utilities for sequences and trees. Nucleic Acids Res. 21, 5264-5272.

Philippe, H., Douzery, E., 1994. The pitfalls of molecular phylogeny based on four species as illustrated by the Cetacea/Artiodactyla relationships. J. Mammal. Evol. 2, 133-152.

Rietschel, S., Storch, G., 1973. Außgewöhlich erhaltene Waldmäuse (Apodemus atavus Heller, 1936) aus dem ber-Pliozän von Willershausen am Harz. Senkenberg. Lethaea 54, 491-519.

Robinson, M., Gouy, M., Gautier, C., Mouchiroud, D., 1998. Sensitivity of the relative-rate test to taxonomic sampling. Mol. Biol. Evol. 15, 1091-1098.

Sambrook, J., Fritsch, E.F., Maniatis, T., 1989. Molecular Cloning: A Laboratory Manual. Cold Spring Harbor Laboratory Press, Cold Spring Harbor, NY.

Serizawa, K., Suzuki, H., Tsuchiya, K., 2000. A phylogenetic view on species radiation in Apodemus inferred from variation of nuclear and mitochondrial genes. Biochem. Genet. 38, 27-41.

Sourrouille, P., Hänni, C., Ruedi, M., Catzeflis, F., 1995. Molecular systematics of Mus crociduroides, an endemic mouse of Sumatra (Muridae: Rodentia). Mammalia 59, 91-102.

Stanhope, M.J., Czelusniak, J., Si, J.S., Nickerson, J., Goodman, M., 1992. A molecular perspective on mammalian evolution from the gene encoding interphotoreceptor retinoid binding protein, with convincing evidence for bat monophyly. Mol. Phylogenet. Evol. 1, $148-160$.

Stanhope, M.J., Smith, M.R., Waddell, V.G., Porter, C.A., Shivji, M.S., Goodman, M., 1996. Mammalian evolution and the interphotoreceptor retinoid binding protein (IRBP) gene: Convincing evidence for several superordinal clades. J. Mol. Evol. 43, 83-92.
Storch, G., 1975. Eine Mittelpleistozäne Nager-Fauna von der Insel Chios, Ägäis (Mammalia, Rodentia). Senkenberg. Biol. 56, 165189

Storch, G., 1987. The Neogene mammalian faunas of Ertemte and Harr Obo in the Inner Mongolia (Nei Mongol), China.-7 Muridae. Senckenberg. Lethaea 67, 401-431.

Strimmer, K., von Haeseler, A., 1996. Quartet puzzling: a quartet maximum likelihood method for reconstructing tree topologies. Mol. Biol. Evol. 13, 964-969.

Suzuki, H., Tsuchiya, K., Takezaki, N., 2000. A molecular phylogenetic framework for the Ryuku endemic rodents Tokudaia osimensis and Diplothrix legata. Mol. Phylogenet. Evol. 5, 15-24.

Sviridenko, 1936. Apodemus ponticus. Works Zool. Inst. Moscow State Univ. 3, 103 .

Swofford, D.L., 1998. PAUP*. Phylogenetic Analysis Using Parsimony (*and Other Methods), ver. 4.0b. Sinauer, Sunderland, MA.

Swofford, D.L., 2000. PAUP*. Phylogenetic Analysis Using Parsimony (*and Other Methods), ver. 4. Sinauer, Sunderland, MA.

Vorontsov, N.N., Boyeskorov, G.G., Mezhzherin, S.V., Lyapunova, E.A., Kandaurov, A.S., 1992. Systematics of the Caucasian wood mice of the subgenus Sylvaemus (Mammalia, Rodentia, and Apodemus). Zool. Z. 71, 119-131.

Wu, C.-I., Li, W.H., 1985. Evidence for higher rates of nucleotide substitutions in rodents than in man. Proc. Natl. Acad. Sci. USA 82, 1741-1745

Yang, Z., 1996. Among-site rate variation and its impact on phylogenetic analyses. Trends Ecol. Evol. 11, 367-372.

Zagorodnyuk, I.V., 1996. Sibling species of mice from Eastern Europe: taxonomy diagnostics and distribution. Proc. Natl. Acad. Sci. USA Russ. 12, 166-175.

Zima, J., 1984. Chromosomes of certain mammals from southern Bohemia and the Sumava Mts. Folia Zool. 32, 132-141. 